\title{
Seroepidemiological Evidence that Shearing Wounds are Mainly Responsible for Corynebacterium pseudo- tuberculosis Infection in Sheep
}

Shin SERIKAWA, Shunsuke ITO, Tadao HATTA, Naohito KUSAKARI, Kazuhiro SENNA, Satoshi SAWARA ${ }^{1)}$, Takashi HIRAMUNE $^{1) *}$, Naoya KIKUCHI ${ }^{1)}$, and Ryo YANAGAWA ${ }^{1)}$

Takikawa Animal Husbandry Experiment Station, 735 Higashi-Takikawa, Takikawa, Hokkaido 073 and "'Department of Epizootiology, School of Veterinary Medicine, Rakuno Gakuen University, Ebetsu, Hokkaido 069, Japan

(Received 8 December 1992/Accepted 12 April 1993)

ABSTRACT. Anti-Corynebacterium pseudotuberculosis toxin titers were examined by an enzyme-linked immunosorbent assay (ELISA) at 3 to 5 month intervals in sheep of three age groups (lambs, 1- and 2-year-old sheep). A significant increase in the ELISA-positive ratio was found only in July, 3 months after shearing, in 1-and 2-year-old sheep. A decrease in the positive ratio was found in the same month in lambs, possibly due to a decrease in maternal antibodies. Since the 1- and 2-year-old sheep had been sheared in April, it was considered that the increase in the positive ratio in July might be closely related to the shearing in April-KEY wORDs: Corynebacterium pseudotuberculosis infection, ELISA-positive ratio, shearing wound.

In most cases of caseous lymphadenitis (CLA) in sheep caused by Corynebacterium pseudotuberculosis it has been assumed that the infection is introduced through superficial skin wounds from shearing, tagging, docking, castration and common wounds [1, 4-5]. Among those wounds, shearing wounds are presumed to be of prime importance [1], based on the results of experimental infection of sheep with organisms through shearing cuts, which resulted in production of CLA lesions [6-7]. No concrete evidence is, however, available to support the relation between infection and shearing.

Recently an ELISA, a sensitive serodiagnostic procedure, has been used in seroepidemiological surveys of CLA to study the seroconversion period in sheep. Paton et al. [8] found an increase in ELISA-positives in 1- and 2-year-old sheep 5 to 7 months after shearing. Chikamatsu et al. [2] also observed a high ELISA-positive ratio of $51.3 \%$ in sheep aged 1 year, but not in sheep less than 1-year-old. The seroconversion might have been due to shearing. However, the 5-7 month period of Paton et al. [8] and the 1-year time frame used by Chikamatsu et al. [2] are considered to be too long to observe the seroconversion.

We have continued the investigation of Chikamatsu et al. [2] by periodic examination of anti-C. pseudotuberculosis toxin ELISA-titers in sheep of three age groups (less than 1 year and 1- and 2-year-old) and verified the assumption that the seroconversion was related to shearing.

Suffolk female sheep bred in the Takikawa Animal Husbandry Experiment Station were used for this study from April 1989 to April 1990. They consisted of three age groups: 98 lambs born in 1989, the year the survey started, 74 1-year-old sheep born in 1988, and 702 -year-old sheep born in 1987. All the sheep were born in February to March, and grazed with their dams from May. They were weaned in June, finished grazing at the end of October, and were housed during winter. The first shearing was

\footnotetext{
* Correspondence to: Hiramune T., Department of Epizootiology, School of Veterinary Medicine, Rakuno Gakuen University, Ebetsu, Hokkaido 069, Japan.
}

done in the following spring. The 2-year-old sheep had lambed in February to March 1989. None showed clinical signs of CLA during the experiment.

All the sheep except lambs were sheared commercially in every April. During the experiment, the 1-year-old sheep were sheared once in April 18-21, 1989, and the 2-year-old sheep were sheared twice, in April 18-22, 1988, and in April 18-21, 1989. As a result, most of them had several shearing cuts.

Serum samples were collected from the lambs and sheep four times: April 12-13, July 17-19 (during grazing), and November 6-7 (1 week after grazing was finished), in 1989; and April 9-11 in 1990. These corresponded to ages of $1,4,8$ and 13 months in lambs; $13,16,20$ and 25 months in 1-year-old sheep; and 25, 28 and 32 months in 2-year-old sheep. The 4th sampling was not done in 2-year-old sheep. Sera were stored at $-20^{\circ} \mathrm{C}$ until used.

The ELISA procedure previously described by Chikamatsu et al. [2] was used to detect antibodies to the toxin antigen of C. pseudotuberculosis ATCC 19410. Sera were absorbed preliminarily with Rhodococcus equi ATCC 33702 (Prescott's serotype 2) to remove non-specific reaction. The optical density (OD) of the contents of each well was measured using an Immuno Reader (MPR-A4; Toyo Soda Industry Co., Tokyo) at a wave length of 405 $\mathrm{nm}$. The cut-off point of OD (0.384) was determined as the mean of the sera from 235 sheep with no CLA lesions plus 3 times the standard deviation according to Chikamatsu et al. [2]. The results were analysed by the $\chi^{2}$ test.

The seasonal ELISA-positive ratios in the three age groups of sheep are shown in Table 1. A significant increase in the positive ratio was found in 1- and 2-year-old sheep in July 1989, 3 months after shearing. No significant increase in the ratio was found in these groups in other seasons. In the lambs, which had not been sheared since birth, the positive ratio decreased to $0 \%$ in July 1989, but slightly increased by the following April.

Paton et al. [8] reported that the ELISA-positive ratio in 1- and 2-year-old sheep increased significantly 5-7 months after shearing, referring to that period as the most susceptible time period for the infection. According to our results, the most susceptible period may be July, 3 months 
Table 1. ELISA-positive ratios in sheep of three age groups

\begin{tabular}{|c|c|c|c|c|c|c|}
\hline \multirow{3}{*}{$\begin{array}{l}\text { Age } \\
\text { group }\end{array}$} & \multirow{3}{*}{$\begin{array}{c}\text { Born in } \\
\text { Feb.-March } \\
\text { in }\end{array}$} & \multicolumn{4}{|c|}{ ELISA-positives in } & \multirow{3}{*}{$\begin{array}{l}\text { Significant difference } \\
\text { between seasons }\end{array}$} \\
\hline & & \multicolumn{3}{|c|}{1989} & \multirow{2}{*}{$\frac{1990}{\text { April }^{\mathrm{D}}}$} & \\
\hline & & April $^{\mathrm{A}}$ & July $^{\mathrm{B}}$ & Nov. ${ }^{\mathrm{C}}$ & & \\
\hline $\begin{array}{l}1 \text { year } \\
\text { old }\end{array}$ & 1988 & $\begin{array}{c}10 / 74^{\mathrm{a})} \\
(13.5 \%)\end{array}$ & $\begin{array}{c}31 / 74 \\
(41.9 \%)\end{array}$ & $\begin{array}{c}33 / 74 \\
(44.6 \%)\end{array}$ & $\begin{array}{c}33 / 74 \\
(44.6 \%)\end{array}$ & $\mathrm{A}$ and $\mathrm{B}(\mathrm{P}<0.01)$ \\
\hline $\begin{array}{l}2 \text { years } \\
\text { old }\end{array}$ & 1987 & $\begin{array}{l}27 / 70 \\
(38.6 \%)\end{array}$ & $\begin{array}{c}46 / 70 \\
(65.7 \%)\end{array}$ & $\begin{array}{c}46 / 70 \\
(65.7 \%)\end{array}$ & $N D^{b)}$ & $\mathrm{A}$ and $\mathrm{B}(\mathrm{P}<0.01)$ \\
\hline Lambs & 1989 & $\begin{array}{l}24 / 98 \\
(24.5 \%)\end{array}$ & $\begin{array}{r}0 / 98 \\
(0 \%)\end{array}$ & $\begin{array}{c}3 / 98 \\
(3.1 \%)\end{array}$ & $\begin{array}{c}10 / 98 \\
(10.2 \%)\end{array}$ & $\begin{array}{l}\mathrm{A} \text { and } \mathrm{B}(\mathrm{P}<0.01) \text { and } \\
\mathrm{C} \text { and } \mathrm{D}(\mathrm{P}<0.05)\end{array}$ \\
\hline
\end{tabular}

a) No. of positive/No. examined. Percentages are shown in parentheses.

b) Not done.

after shearing. In addition, 5-7 months may be too long to accept a conclusion that the seroconversion was due to shearing.

In lambs, the ELISA-positive ratio was $24.5 \%$ in April, but it decreased to $0 \%$ in July. This was possibly due to the declining levels of maternal antibodies. In goat, Holstad [3] had also observed a decrease in the antibodypositive ratio at 3-4 months old. The ELISA-positive ratio in lambs then increased through the next April. The ratio, however, remained much smaller than in 1- and 2-year-old sheep in July. Since the lambs had not been sheared after birth, the increase may be due to non-shearing wounds.

These findings indicate that shearing wounds might be more susceptible to infection by CLA than other wounds, suggesting that CLA may be controlled by proper treatment of wounds immediately after shearing. Studies are in progress to prove this hypothesis.
REFERENCES

1. Blood, D. C., Radostis, O. M., Arundel, J. H., and Gay, C. C. 1989. Veterinary Medicine, 7th ed., Bailliere Tindall, London, Philadelphia, Sydney, Tokyo and Toronto.

2. Chikamatsu, S., Zhao, H. K., Kikuchi, N., and Hiramune, T. 1989. Jpn. J. Vet. Sci. 51: 887-891.

3. Holstad, G. 1986. Acta Vet. Scand. 27: 598-608.

4. Jensen, R. and Swift, B. L. 1982. Diseases of Sheep, 2nd ed., Lea \& Febiger, Philadelphia.

5. Merchant, I. A. and Barner, R. D. 1971. An Outline of the Infectious Diseases of Domestic Animals, 3rd ed., Iowa State University Press.

6. Nagy, G. 1976. J. S. Afr. Vet. Med. Assoc. 47: 197-199.

7. Nairn, M. E. and Robertson, J. P. 1974. Aust. Vet. J. 50: 537-542.

8. Paton, M. W., Mercy, A. R., Sutherland, S. S., and Ellis, T. M. 1988. Acta Vet. Scand. (Suppl.) 84: 101-103. 